\title{
ANALYSIS OF THE IN VITRO ADHERENCE OF Streptococcus mutans AND Candida albicans
}

\author{
Dicler de Sant'Anna Vitor Barbieri' ${ }^{1,2}$; Vânia Aparecida Vicente ${ }^{1 *}$; Fabian Calixto Fraiz²; Osmir José Lavoranti; \\ Terezinha Inês Estivalet Svidzinski ${ }^{4}$; Rosângela Lameira Pinheiro ${ }^{5}$
}

${ }^{1}$ Departamento de Patologia Básica, Universidade Federal do Paraná, Curitiba, PR, Brasil; ${ }^{2}$ Departamento de Estomatologia, Universidade Federal do Paraná, Curitiba, PR, Brasil; ${ }^{3}$ Centro Nacional de Pesquisa de Florestas, Empresa Brasileira de Pesquisa Agropecuária, Colombo, PR, Brasil; ${ }^{4}$ Laboratório de Micologia do Hospital de Clínicas, Universidade Federal do Paraná, Curitiba, PR, Brasil; ${ }^{5}$ Departamento de Análises Clínicas, Universidade Estadual de Maringá, Maringá, PR, Brasil

Submitted: October 19, 2006; Returned to authors for corrections: April 02, 2007; Approved: July 27, 2007.

\begin{abstract}
The objective of the present study was to investigate the in vitro adherence capacity of Streptococcus mutans and Candida albicans. Adherence assays were conducted on dental surfaces and analyzed by scanning electron microscopy (SEM). Extracted human teeth were inoculated with Streptococcus mutans or Candida albicans and with both species simultaneously, and incubated at $37^{\circ} \mathrm{C}$ for 21 days. Bacterial inocula had been obtained from saliva samples of children that had been colonized by both organisms. ATCC reference strains were used as controls. SEM analyses showed that the biofilm that covered the entire analyzed dental surface was more homogeneous inoculated with the two microorganisms simultaneously than with each species separately. In a second experiment, carried out with isolates that had shown the highest adherence the isolates were tested for adherence to high-density polyethylene substrates. The potentialization of the adherence capacity of Streptococcus mutans and Candida albicans when in association was confirmed.
\end{abstract}

Key words: Adherence, Candida albicans, Streptococcus mutans, biofilm

\section{INTRODUCTION}

The buccal microbiota plays an important role in maintaining oral health, as well as in the occurrence of diseases resulting from disturbance to this ecosystem. The organisms that compose this biota contribute to the development of the host immune system, allowing for a balanced colonization of a large variety of microorganisms. However, they also constitute a reservoir of microorganisms that can potentially invade other tissues of their host. The complexity of this ecosystem depends on the age and immunocompetence of the host, the availability of new niches, dietary changes, the quality and frequency of oral hygiene, and the exposure to fluoride $(16,20)$.

One of the buccal diseases that reflects a lack of equilibrium of this microbiota is caries, which causes the destruction of dental mineralized tissues during its progression. Its main etiological agent is the bacterium Streptococcus mutans, which is capable of adhering to dental surfaces and initiating the formation of the cariogenic bacterial plaque. The metabolic system of this bacterium generates an acidogenic niche that exceeds the salivary buffering capacities, triggering progressive changes in the mineral layer of the dental surface $(11,18)$.

The concentration of $S$. mutans is often high in the saliva of patients with elevated levels of dental caries. Several factors related to the oral environment are though to contribute to the establishment and multiplication of $S$. mutans $(11,15)$.

Candida albicans can be found in several locations on the human body due to its opportunistic nature, at times invading tissues to cause candidosis when in association with predisposing factors. In addition, the capacity of tissue invasion and adhesion to artificial materials such as probes, latex catheters, and several types of plastic material are responsible

*Corresponding Author. Mailing address: UFPR - Dep. de Patologia Básica - Setor de Ciências Biológicas - Centro Politécnico - Jd. das Américas, 81531-990 Curitiba, PR - Brasil. Tel.: (41) 3356-1353 ou (41) 3266-2042. E-mail: vicente@ufpr.br 
for causing important infections (34). In the case of dental biofilms, its role in coaggregation with $S$. mutans during the mechanisms of microbial adherence to the dental surface has been the focus of research $(2,13,26,32,35)$. In addition, the adherence to acrylic prostheses has been often investigated $(7,19,21,22,29,31)$.

Candida albicans has been isolated in dental biofilms $(2,8,31,32)$ and its role in microbial adherence to dental surfaces in coaggregation with $S$. mutans has been studied in recent years (35). The presence of $C$. albicans has already been recorded in caries lesions, as well as its capacity to invade mouth tissues and artificial materials such as acrylic, which is used in several types of dental prostheses $(1,3,7,20,22,26)$.

The hypothesis of the association between $S$. mutans and C. albicans is based on their mechanisms of virulence and biochemical characteristics, as well as the endogenous and exogenous factors that cause the host to provide a buccal environment that favors the action of both microorganisms $(1,23,35)$.

The analysis of the in vitro adherence of $S$. mutans and $C$. albicans can contribute to the understanding of the behavior of these organisms in the dental plaque. Thus, the present study reports on an in vitro adherence assay using human teeth as the adherence surface and inocula of $S$. mutans and $C$. albicans isolated from saliva samples of children colonized by both microorganisms, as well as reference strains. The goal of these assays is to investigate the adherence capacity of these species, both in isolation and in combination in dental biofilms. A second assay was carried out to assess the same phenomenon on highdensity polyethylene surfaces.

\section{MATERIALS AND METHODS}

The present study has been approved by the Research Ethics Committee of the Institute of Health Sciences of the Universidade Federal do Paraná.

\section{Yeasts and Bacterial strains}

The in vitro adherence study using human teeth included 6 isolates of $S$. mutans (M1, M2, M3, M4, M5, and M6) and 6 isolates of $C$. albicans $(\mathrm{C} 1, \mathrm{C} 2, \mathrm{C} 3, \mathrm{C} 4, \mathrm{C} 5$, and $\mathrm{C} 6)$. The isolates of $S$. mutans and C. albicans were obtained from saliva samples of children colonized by both species that were treated at the Odontopediatric Clinic of the Universidade Federal do Paraná, Brazil. ATCC reference strains of both species (C. albicans, 10123 and S. mutans, 25175) were also used.

\section{Isolation and identification of microorganisms}

The isolation of $C$. albicans was carried out by submitting the non-stimulated saliva samples to decimal dilutions of saline solutions $\left(10^{-1}\right.$ and $\left.10^{-2}\right)$, inoculating them on Sabouraud Dextrose Agar, and incubating them at $30^{\circ} \mathrm{C}$ for $48 \mathrm{~h}$ to 7 days.
The isolation of S. mutans from the same samples was conducted by submitting the saliva samples to decimal solutions of peptone water $\left(10^{-1}, 10^{-2}\right.$, and $\left.10^{-3}\right)$, inoculated on Mitis Salivarius Agar (Difco) containing bacitracin $(30 \mu \mathrm{g} / \mathrm{mL})$ and potassium telurite $(0.001 \%)$, and incubated in microaerophilia in GasPak jars at $37^{\circ} \mathrm{C}$ for $48 \mathrm{~h}$. Identification was carried out using morphological and biochemical traits, both for $S$. mutans $(10,17,27)$ and for yeasts of the Candida genus $(14,17,28)$. Molecular markers (27) were used to confirm the identity of the $S$. mutans isolates through specific PCR using primers (1-ACTACACTTTCGGGTGGCTTGG and 2CAGTATAAGCGCCAGTTTCATC) and the isolates were maintained and preserved in glycerol at $-80^{\circ} \mathrm{C}$. Isolates of $C$. albicans were confirmed using an automated system $\left(\right.$ Vitek $\left.^{\circledR}\right)$ of biochemical identification $(14,28)$.

\section{Inoculate preparation for the adherence assay on the dental surface}

Inocula were prepared from 6 isolates of $S$. mutans and 6 isolates from $C$. albicans obtained with the abovementioned protocol, as well as from ATCC reference strains (C. albicans 10231 and S. mutans 25175). Isolates of S. mutans were cultured at $37^{\circ} \mathrm{C}$ for $18 \mathrm{~h}$ and standardized to a cell suspension with an optical density of $2.1 \times 10^{9}$ cells $/ \mathrm{mL}$ using spectrophotometry and counting of colony-forming units (CFUs) in TSB agar. Likewise, isolates of $C$. albicans were standardized to a final concentration of $2.1 \times 10^{8}$ cells $/ \mathrm{mL}$, with a later colony count in Saboraud medium.

\section{Tooth adherence assay}

An adherence assay for $S$. mutans and $C$. albicans was developed based on Yoshiyasu (36). A total of 21 healthy premolar human teeth that had been extracted for orthodontic purposes were donated by the patients to be used in the adherence tests. The teeth were kept in saline solution, which was replaced weekly until the beginning of the experiments. Before inoculation, each tooth was cleaned mechanically using limestones and water, as well as a Robson brush mounted on a hand piece. Following the mechanical cleaning, each tooth was perforated using a round diamond drill (Sorensen $n^{\circ} 2$ ), creating a hole through which a piece of dental floss was inserted to facilitate their handling during the experiments. Each tooth was introduced into a test tube containing $9 \mathrm{~mL}$ of the Gibbons and Nygaard culture medium (9), and autoclaved at 1 atm and $121^{\circ} \mathrm{C}$ for $20 \mathrm{~min}$. One $\mathrm{mL}$ of either previously standardized inoculate was then added to the tube in the monospecific culture, whereas the combined culture included $1 \mathrm{~mL}$ of the standardized inoculum of each species.

Incubation lasted for 21 days, replacing of their culture medium every $48 \mathrm{~h}$, followed each time by a check for contamination by optical microscopy using Gram staining (36). The presence of coaggregates in the medium, degree of 
precipitation, and the intensity of the visible biofilm in the crown and the root were used as criteria to assess the adherence patterns of clinical isolates and reference strains of C. albicans, S. mutans, and both microorganisms in association (5).

\section{Scanning electron microscopy}

Each tooth was fixated in Karnovsky solution, washed three times using a $0.05 \mathrm{M}$ sodium cacodilate buffer solution ( $\mathrm{pH} 7.4$ ), and then cut with Isomet Cut-off Rotary Instrument. Cuts were dehydrated in an increasing series of Acetone solutions (30\%, $50 \%, 90 \%, 100 \%$ and $100 \%$ ), dried under room temperature, and metallized using a MED 010 (Balzers $\left.{ }^{\circledR}\right)$. Observations were carried out in a JSM-6360LV microscope at the Center for Electron Microscopy of the UFPR.

\section{Assay of adherence on high-density polyethylene}

Inocula were prepared from 3 isolates of $C$. albicans $(\mathrm{C} 1$, $\mathrm{C} 2$, and C4) and 3 isolates from S. mutans (M1, M2, and M4). These isolates were chosen based on qualitative differences in their adherence patterns according to Barbieri (5). In addition, ATCC reference strains of $C$. albicans 10231 and $S$. mutans 25175 were also included. Based on the protocol of Tamura et al. (34), isolates were cultivated at $37^{\circ} \mathrm{C}$ for $18 \mathrm{~h}$ and their concentrations were standardized to $2.1 \times 10^{8}$ cells $/ \mathrm{mL}$ using spectrophotometry. A total of 12 inocula were prepared using S. mutans (M), C. albicans (C), or both S. mutans and C. albicans $(\mathrm{M}+\mathrm{C})$. A total of 12 acrylic sheets with dimensions $0.5 \mathrm{~cm} \mathrm{X2.5}$ $\mathrm{cm}$ X $0.5 \mathrm{~mm}$ were placed in individual test tubes containing $0.9 \mathrm{~mL}$ of Gibbons and Nygaard culture medium and $0.1 \mathrm{~mL}$ of the inoculate. Culture was carried out at $37^{\circ} \mathrm{C}$ for different incubation periods $(2,12,24,48$, and $72 \mathrm{~h})$, with one repetition for each analyzed period.

After each incubation period, the high-density polyethylene sheet were washed three times using phosphate buffered saline (PBS) to remove weakly adhered cells. The fragments were then placed on a magnetic stirrer with two glass pearls for $30 \mathrm{~s}$ to detach the cells that had adhered to polyethylene fragment and to release them into a suspension. Each suspension sample was used to create three decimal dilutions in PBS $\left(10^{-1}, 10^{-2}\right.$, and $10^{-3}$ ), which were then plated on Petri dishes with Gibbons and Nygaard agar. The whole protocol was repeated twice. Plate culture was conducted at $37^{\circ} \mathrm{C}$ for $48 \mathrm{~h}$, followed by an estimated count of CFU/mL. This value was used as an approximation to the total adherence for each $1 \mathrm{~cm}^{2}$ of the high-density polyethylene.

\section{Statistical analysis of the adherence to high-density polyethylene}

Average adherence values were assessed by an analysis of variance (ANOVA) according to a completely randomized design with two replicates and a factorial distribution of the treatments: monospecific culture of clinical isolates and reference strains of $S$. mutans (M), C. albicans (C) and the combined culture of both species $(\mathrm{M}+\mathrm{C})$ and culture times (2, 12, 24, 48, and $72 \mathrm{~h}$ ). Multiple comparisons were processed using the orthogonal contrasts of the $\mathrm{F}$ test according to Hinkelmann and Kempthorne (12).

\section{RESULTS}

SEM analyses of the colonized teeth showed that, when the six isolates and reference strain of $S$. mutans were cultivated separately, the adherence to the dental surface was characterized by a thick compact biofilm, with tightly grouped cells of uniform size and morphology (Fig. 1A), although that pattern was not observed in some regions of the biofilm (Fig. 2A). When clinical isolates and reference strain of $C$. albicans were cultivated separately, the biofilm showed the presence of cellular morphology with a predominance of filaments (Fig. 1B). The biofilm formed by $C$. albicans under these conditions was characterized by a thinner aspect (Fig. 2B). However, there was greater uniformity in the biofilm, with all regions of the tooth being equally colonized (Fig. 1B). When both microorganisms were associated, the biofilm was more homogeneous, covering the entire dental surface (Fig. 2C). In addition, there was an extensive colonization of the cellular surface of the yeast by cells of S. mutans. An abundant amorphous substance was present in the interstices between the cells of both species (Fig. 1C). The cells of C. albicans, when in association with $S$. mutans, showed structures such as blastopores, pseudohyphae, and germ tubes covered by amorphous extra-cellular structures (Fig. 1D).

Adherence analysis on the acrylic surface used isolates M1, M2, and M4 of S. mutans and C1, C2, and C4 of C. albicans, which had been selected based on visualization of the adherence patterns using SEM and the presence metabolic products in the culture medium, as described in the Materials and Methods section. The results obtained from the tests of adherence on the high-density polyethylene models are presented in Fig. 3 (A, B), showing estimated adherence values in $\mathrm{CFU} / \mathrm{cm}^{2}$. No increase in the number of adhered viable cells was evident after 48h (Fig. 3A, B) except in the case of clinical isolates of $C$. albicans that had been cultivated separately (Fig. 3B).

There was considerable variation in adherence over in the $48 \mathrm{~h}$ period among the studied clinical isolates and reference strains. However, S. mutans in association with C. albicans had higher adherence than either species separately (Fig. 3A). A statistically significant increase in the adherence of $S$. mutans was observed in the association with $C$. albicans in relation to the monospecific treatment in the $48 \mathrm{~h}$ period $(\mathrm{p}=0.0078$, Table 1 ), where clinical isolates showed a higher number of adhered cells in relation to the reference strains of S. mutans (Fig. 3A, Table1). 

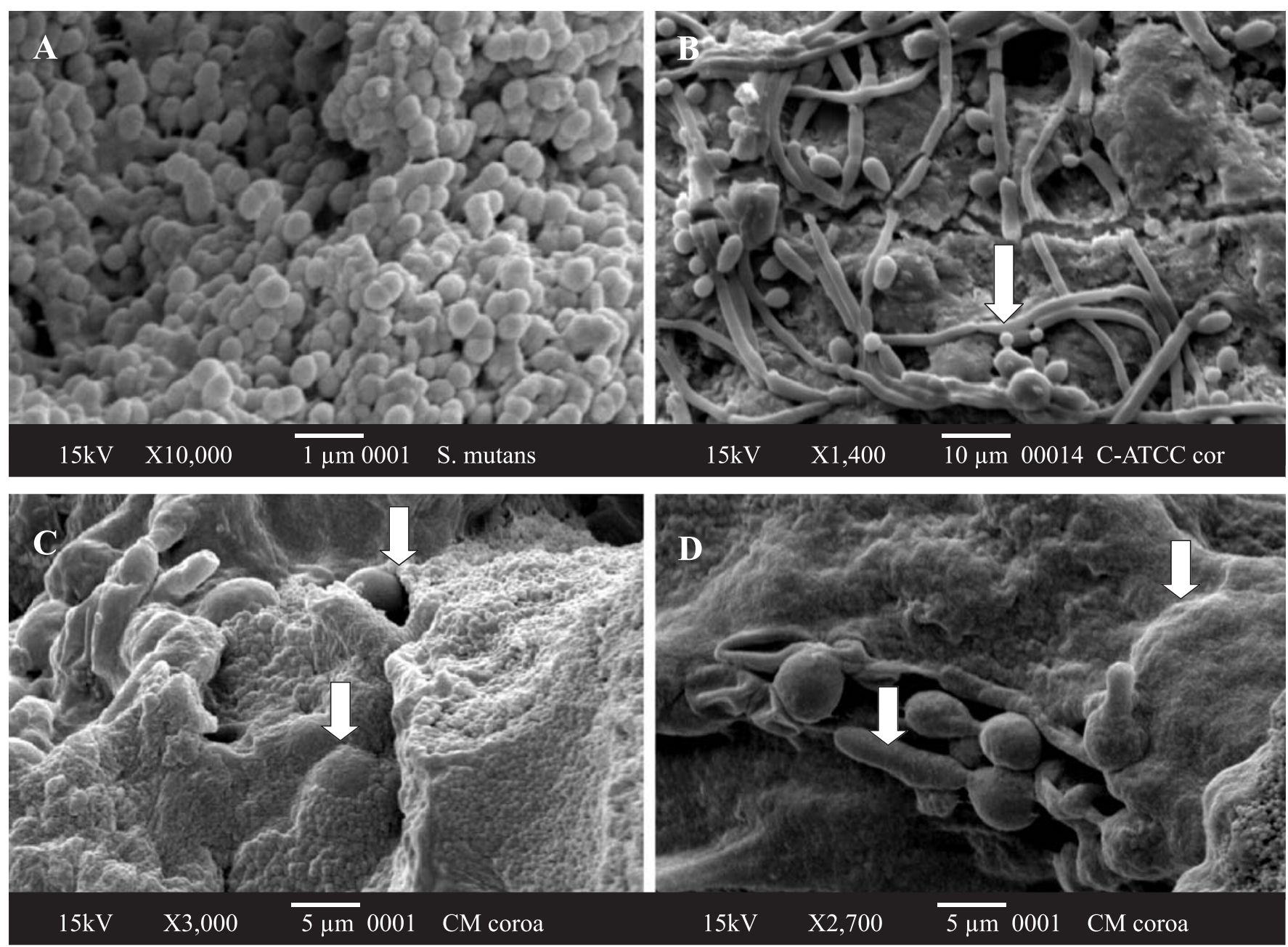

Figure 1. Scanning Electron Micrographs showing the in vitro adherence to the dental surface after 21 days of cultivation in Gibbons \& Nygaard medium (9) A - Magnification of 10000x of adherence pattern of S. mutans cells on the dental surface showing tightly grouped cells of uniform size and morphology. B - Magnification of 1400x Adherence pattern of C. albicans cultured separately on the dental surface. Arrow = Filamentous morphology of cells showing budding with all regions of the tooth being equally colonized C- Magnification of 3000x C. albicans in association with S. mutans on dental surface. Arrows = Abundant amorphous extracellular structures are seen covering the surface of the yeast cells and providing support of adherence. DMagnification of 2700x C. albicans in association with S. mutans on the dental surface. Arrow = Abundant amorphous extracellular structures are seen between cocci and yeast cells. Arrow $=$ Candid $a$ cells exhibiting germ tubes .

Likewise, clinical isolates and reference strains of $C$. albicans showed a smaller number of viable adhered cells separately than in association (Fig. 3A). However, when cultivated separately, reference strains of $C$. albicans showed a larger number of adhered cells in relation to clinical isolates, particularly in the $48 \mathrm{~h}$ period (Fig. 3B, Table 1).

C. albicans cultivated separately showed an increase in the number of viable adhered cells until 72 h (Fig. 3B), whereas $S$. mutans began declining after $48 \mathrm{~h}$ (Fig. 3A), both for reference and clinical strains.

\section{DISCUSSION}

Based on the SEM images, the predominant morphology of C. albicans cells when cultivated separately was the filamentous form (Fig. 1B), a pattern that could indicate that this situation favors cellular morphologies with higher capacity for tissue invasion, possibly due to the absence of competition as previously reported $(33,35)$.

The combined colonization of $S$. mutans and $C$. albicans (both in the case of clinical isolates and reference strains) 

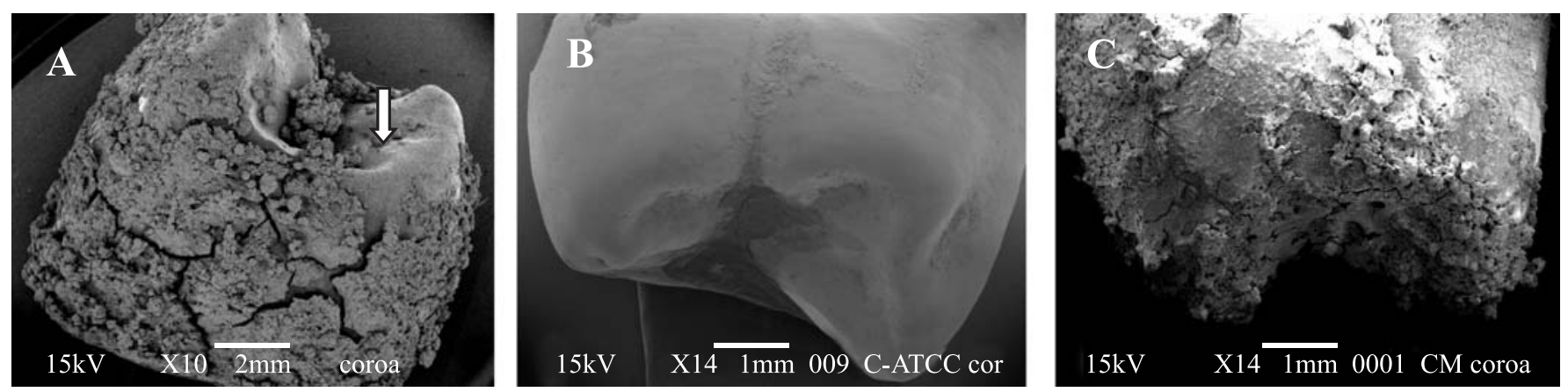

Figure 2. Scanning Electron Micrographs showing the in vitro adherence to the dental surface after 21 days of cultivation in Gibbons \& Nygaard medium (9) A - Magnification of 10x of the thick compact biofilm formed by S. mutans, showing the detachment of the biofilm (arrow). B - Magnification of 14x, thin and weakly evident biofilm formed by C. albicans. C - Magnification of 14x, biofilm formed by $S$. mutans and $C$. albicans, with the entire dental surface covered by a homogeneous biofilm.

Table 1. $\mathrm{P}$ value of the orthogonal contrasts of the $\mathrm{F}$ test of the concentration of viable adhered cells on high-density polyethylene of clinical isolates and reference strain of $S$. mutans and C. albicans cultivated separately and in association.

\begin{tabular}{|c|c|c|c|c|c|}
\hline \multirow{2}{*}{ Studied species } & \multicolumn{5}{|c|}{ Time (h) } \\
\hline & \multicolumn{5}{|c|}{ Clinical isolates of $S$. mutans } \\
\hline Isolates of $S$. mutans in association & 0.2176 & 0.2622 & 0.2324 & 0.0078 & 0.0221 \\
\hline Reference strain of $S$. mutans & 0.5393 & 0.3393 & 0.1818 & 0.0085 & 0.0343 \\
\hline \multirow[t]{2}{*}{ Reference strain of $S$. mutans in association } & 0.2222 & 0.2417 & 0.1947 & 0.0001 & 0.0331 \\
\hline & \multicolumn{5}{|c|}{ Clinical isolates of $S$. mutans in association } \\
\hline Reference strain of $S$. mutans & 0.6171 & 0.3941 & 0.2674 & 0.0076 & 0.0013 \\
\hline \multirow[t]{2}{*}{ Reference strain of $S$. mutans in association } & 0.6315 & 0.3741 & 0.2598 & 0.0042 & 0.6468 \\
\hline & \multicolumn{5}{|c|}{ Reference strain of $S$. mutans } \\
\hline Reference strain of $S$. mutans in association & 0.3222 & 0.3833 & 0.2899 & 0.4463 & 0.0087 \\
\hline Reference strain of $C$. albicans in association & \multicolumn{5}{|c|}{ Clinical isolates of $C$. albicans in association } \\
\hline Reference strain of $C$. albicans & 0.2059 & 0.4028 & 0.6315 & 0.0043 & 0,7401 \\
\hline \multirow[t]{2}{*}{ Reference strain of $C$. albicans in association } & 0.1573 & 0.6468 & 0.5485 & 0.0017 & 0.0309 \\
\hline & \multicolumn{5}{|c|}{ Reference strain of $C$. albicans } \\
\hline Reference strain of $C$. albicans in association & 0.3455 & 0.4583 & 0.5169 & 0.0001 & 0.0134 \\
\hline
\end{tabular}

indicated the in vitro adherence of the biofilm throughout the entire dental surface, forming a network of cells of both microorganisms together with an amorphous substance that filled the space between cells (Fig. 1C, D). These observations are consistent with previous reports assessing the adherence of $C$. albicans in the presence of bacteria $(4,30,35)$. These studies have shown that the associated microorganisms form an extensive network, such that the mature biofilm comprise all morphologies of the present microorganisms embedded in an exopolimeric matrix material.

The intensity of the colonization by $S$. mutans was more extensive when cultivated with $C$. albicans, indicating a possible 

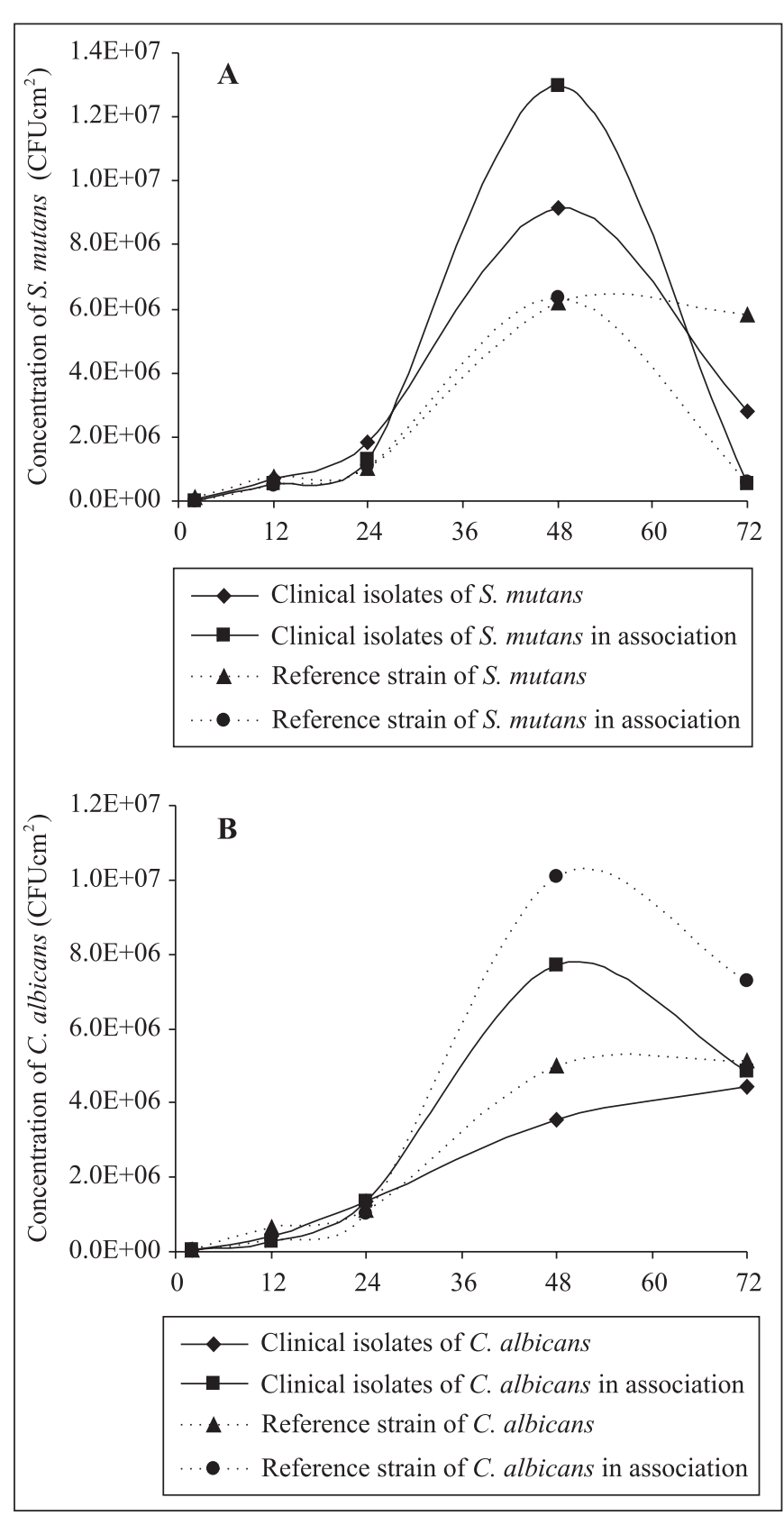

Figure 3. Median adherence value in $\mathrm{CFUs} / \mathrm{cm}^{2}$ of the concentration of viable adhered cells in the high-density polyethylene of clinical isolates and reference strain of S. mutans and $C$. albicans cultivated separately and in association.

facilitation mechanism during this association, where the yeast cells could be used by the bacteria as support for their adherence. The most common morphology of $C$. albicans when in association with $S$. mutans is the yeast-like form, with the formation of blastospores. This can be explained by the presence of $S$. mutans and its metabolic products, which would hamper the formation of the filamentous forms, although a few germinative tubes could be observed (Fig. 1D), as previously reported by Thein et al. (35).

According to Soll (33), C. albicans is capable of differentiation, showing yeast-like and filamentous developmental forms in association with both disease and commensalism, although the yeast-like form is more prevalent in the case of comensalism. Nikawa et al. (24) analyzed the coadherence of $C$. albicans with oral bacteria and also found a predominance of blastospores during the co-adhesion with $S$. mutans in a culture medium supplemented with sucrose. These authors considered the coaggregation as a key factor in the ecology of oral biofilms. Due to the colonization and virulence factors of C. albicans, its presence in microbiotas with caries activity is expected given that it is an aciduric, dentinophilic microorganism with high adherence capacity (1). Given that $C$. albicans has efficient adherence mechanisms, its colonization of the oral environment might represent a predisposing factor favoring its interaction with $S$. mutans, as has been suggested by several authors $(1,23,26,35)$. Most studies on the in vitro interaction between two microorganisms use either reference strains or isolates from different hosts $(6,24-26)$. The use of isolates from hosts colonized by both microorganisms can be a starting point to future findings in specific populations.

The interaction of $C$. albicans and $S$. mutans in a combined culture can be understood as mutualistic, given that both microorganisms seem to be favored. In particular, the amorphous substance observed in the interstices between cells seems to play an important role in this interaction. This observation might also explain the formation of aggregates in the culture medium during the combined culture on teeth. Branting et al. (6) studied the adherence behavior of $C$. albicans in association to $S$. mutans in acrylic surfaces and suggested that the presence of insoluble glucans produced by $S$. mutans could increase the adhesive capacity of the yeast in combined cultures. Nikawa $e t$ al. (24) also detected coaggregates composed of bacterial cells covering the surface of yeast cells using SEM, although in that case no adherence substrate was provided.

The in vitro adherence to high-density polyethylene observed in the present study confirmed the results from SEM, showing that the association favored the adhesion of both microorganisms. Previous studies demonstrate the benefits of microorganism interactions $(4,8,16,29,30)$, although it is likely that antagonistic interactions also play an important role in mixed biofilm. In particular, the $48 \mathrm{~h}$ period was the most favorable to $S$. mutans (p-value $=0.0078$, Table 1 ). From that time onward, the number of adhered viable cells of $S$. mutans decreases substantially (Fig. 3A), whereas C. albicans still showed viable adhered cells until the $72 \mathrm{~h}$ period, as observed by Thein et al. (35). However, when in association, both species showed a decrease in the number of adhered cells after $48 \mathrm{~h}$ 
(Fig. 3A, B). This pattern might have resulted from competition within the same niches, the physical presence of the bacterial, the effect of bacterial metabolites in the development of the biofilm, and the nutritional requirements of the component species, as suggested by Thein et al. (35).

Clinical isolates of $S$. mutans obtained from coinfected children showed a higher number of viable adhered cells in the polyethylene assay, when compared to the respective reference strain (Table 1). This difference indicates that the clinical isolates show considerable adherence potential, which is even higher when in association (Fig. 3A). A different behavior was found in the case of $C$. albicans, in which the adherence is lower in the clinical isolates in relation to the reference strains (Fig. 3B). These results indicate that coinfection indeed leads to an increase in the adherence potential. Moreover, there seems to be considerable variation among strains in their adherence capacity, particularly when comparing clinical and reference strains.

Although in vitro studies can help the understanding of these associations, the dynamics of this interaction in the oral environment in the presence of other microorganisms, the immunocompetence of the host and other factors such as diet and oral hygiene can play an important regulatory function (16), and can provide a prolific area for future research. According to our results, as well as previous studies, there is strong evidence that $C$. albicans might favor the in vitro adherence of S. mutans in the dental biofilms, thus favoring its colonization. Research in this area corroborates the suggestion by Moalic et al. (23) that the presence of $C$. albicans in the oral environment can be considered as an additional factor that needs to be taken into account in evaluating risks to caries.

\section{RESUMO}

\section{Análise da aderência in vitro de Streptococcus mutans e Candida albicans}

O objetivo deste trabalho foi investigar a capacidade de aderência in vitro de Streptococcus mutans e Candida albicans. Ensaios de aderência foram realizados in vitro na superfície dentária, com posterior análise por Microscopia Eletrônica de Varredura (M.E.V.). Dentes humanos extraídos foram inoculados com Streptococcus mutans e Candida albicans, além de ambas espécies em conjunto, e foram incubados a $37^{\circ} \mathrm{C}$ por 21 dias. Os inóculos eram provenientes de amostras salivares de crianças colonizadas por ambos microrganismos. Como controles foram utilizadas linhagens de referência ATCC dos dois microrganismos. A análise por M.E.V. mostrou a formação de um biofilme que cobriu toda a superfície dentária analisada de forma mais homogênea quando incubados juntos do que separadamente. Um segundo experimento foi desenvolvido utilizando isolados mostrando maior aderência dos experimentos anteriores e cortes de polietileno de alta densidade como substrato. A potencialização da capacidade de aderência de Streptococcus mutans e Candida albicans em associação foi confirmada.

Palavras-chave: Aderência, Candida albicans, Streptococcus mutans, biofilme

\section{REFERENCES}

1. Akdeniz, B.G.; Koparal, E.; Sen, B.H.; Ates, M.; Denizci, A.A. (2002). Prevalence of Candida albicans in oral cavities and root canals of children. J. Dent. Child., 69(3), 289-292.

2. Arendorf, T.M.; Walker, D.M. (1980). The prevalence and intraoral distribution of Candida albicans in man. Arch. Oral Biol., 25, $1-10$.

3. Baena, M.T.; Moreno, M.M.V.; Franco, M.F.; Adalpe, B.B.; Quindos, G.; Sanches, V. L.O. (2005). Candida albicans, Sthaphylococcus aureus and Streptococcus mutans colonization in patients wearing dental prosthesis. Med. Oral Patol. Oral Cir. Bucal., 10(1), 27-39.

4. Baillie, G.S.; Douglas, L.J. (1999). Role of dimorphism in the development of Candida albicans biofilms. J. Med. Microbiol., 48, 671-679.

5. Barbieri, D.S.V. (2005). Análise da aderência in vitro de Streptococcus mutans e Candida albicans na superfície dentária. Curitiba, Brasil, 92 p. (M. Sc. Dissertation. Universidade Federal do Paraná).

6. Branting, C.; Sund, M-L.; Linder, L.E. (1989). The influence of Streptococcus mutans on adhesion of Candida albicans to acrylic surfaces in vitro. Arch. Oral Biol., 34, 347-353.

7. Cannon, R.D.; Holmes, A.R.; Mason, A.B.; Monk, B.C. (1995) Oral Candida: clearence, colonization or Candidiasis. J. Dent. Res., 74, 1152-1161

8. El Azizi, M.A.; Starks, S.E.; Khardori, N. (2004). Interactions of Candida albicans with other Candida spp. And bacteria in the biofilms. J. Appl. Microbiol., 96, 1067-1073.

9. Gibbons, R.J.; Nygaard, M. (1968). Synthesis of insoluble dextrand its significance in the formation of gelatinous deposits by plaque forming streptococci. Arch. Oral Biol., 13, 1249-1262.

10. Gold, O.G.; Jordan, H.V.; Van Houte, J.A. (1973). Selective medium for Streptococcus mutans. Arch. Oral Biol., 18(11), 1357-1364.

11. Grönroos, L. (2000). Quantitative and Qualitative Characterization of Mutans Streptococci in Saliva and in the Dentition. Helsinki, 80 p. (Academic Dissertation. Department of Pedodontics and Orthodontics, Institute of Dentistry, University of Helsinki and Department of Oral and Maxillofacial Diseases, Helsinki University Central Hospital).

12. Hinkelmann, K.; Kempthorne, O. (1994). Design and analysis of experiments. vol.1: Introduction to Experimental Design. John Wiley \& Sons, New York, USA.

13. Holmes, A.R.; Gopal, P.K.; Jenkinson, H.F. (1995). Adherence of Candida albicans to a cell surface polysaccharide receptor on Streptococcus gordonii. Infect. Immun., 63, 1827-1834.

14. Kellogg, J.A.; Bankert, D.A.; Chaturvedi, V. (1998). Limitations of the current microbial identification system for identification of clinical yeast isolates. J. Clin. Microbiol., 36(5), 1197-1200.

15. Koga-Ito, C.Y.; Unterkircher, C.S.; Watanabe, H.; Martins, C.A.P.; Vidotto, V.; Jorge, A.O.C. (2003). Caries risk tests and salivary levels of immunoglobulins to Streptococcus mutans and Candida albicans in mouthbreathing syndrome patients. Caries Res., 37, 38-43.

16. Kolenbrander, P.E. (2000). Oral microbial communities: biofilms, interactions and genetic systems. Annu. Rev. Microbiol., 54, 413437. 
17. Koneman, E.W.; Allen, S.D.; Janda, W.M.; Schreckenberger, P.C.; Winn Jr., W.C. (1997). Color Atlas and Textbook of Diagnostic Microbiology $-5^{\text {th }}$ edition. Lippincott-Raven Publishers.

18. Kreulen, C.M.; De Soet, H.J.; Hogeveen, R.; Weerkamp, J. S. (1997). Streptococcus mutans in children using nursing bottles. J. Dent. Child., 64, 107-111.

19. Kuhn D.M.; Chandra J.; Mukherjee P.K.; Ghannoum M.A. (2002). Comparison of biofims formed by Candida albicans and Candida parapsilosis on bioprosthetic surfaces. Infect. Immun., 70, 878-888.

20. Marcotte, H.; Lavoie, M.C. (1998). Oral microbial ecology and the role of salivary imunoglobulin A. Microbiol. Mol. Biol. Rev., 62, 71109.

21. Masella, R.P.; Dolan, C.T.; Laney, W.R. (1975). The prevention of the growth of Candida on Silastic 390 soft liner for dentures. $J$. Prosthet. Dent., 33, 250-257.

22. Minagi, S.; Miyake, Y.; Inagaki, K.; Tsuru, H.; Suginaka, H. (1985). Hydrophobic interaction in Candida albicans and Candida tropicalis adherence to various denture base resin materials. Infect. Immun., 47, 11-14

23. Moalic, E.; Gestalin, A.; Quinio, D.; Gest, P.E.; Zerili, A.; Le Flohic, A.M. (2001). The extent of oral fungal flora in 353 students and possible relationships with dental caries. Caries Res., 35, 149-155.

24. Nikawa, H.; Egusa, H.; Makihira, S.; Yamashiro, H.; Fukushima, H.; Jin, C.; Nishimura, M.; Pudji, R.R.; Hamada, T. (2001). Alteration of the coadherence of Candida albicans with oral bacteria by dietary sugar. Oral Microbiol. Immunol., 16, 279-283.

25. Nikawa, H.; Hamada, T.; Yamashiro, H.; Murata, H.; Subiwahjudi, A. (1998). The effect of saliva or serum on Streptococcus mutans and Candida albicans colonization of hydroxyapatite beads. J. Dent., 26, 31-37.

26. Nikawa, H.; Yamashiro, H.; Makihira, S.; Nishimura, M.; Egusa, H.; Furukawa, M.; Setijanto, D. (2003). In vitro cariogenic potential of Candida albicans. Mycoses, 46, 471-478.
27. Oho, T.; Yamashita, Y.; Shimazaki, Y.; Kushiyama, M.; Koga, T. (2000). Simple and rapid detection of Streptococcus mutans and Streptococcus sobrinus in human saliva by polymerase chain reaction. Oral Microbiol. Immunol., 15(4), 258-262.

28. Pincus, D.H.; Coleman, D.C.; Pruitt, W.R.; Padhye, A.A.; Salkin, I.F.; Geimer, M.; Bassel, A.; Sullivan, D.J.; Clarke, M.; Hearn, V. (1999). Rapid identification of Candida dubliniensis whith commercial yeast identification systems. J. Clin. Microbiol., 37(11), 3533-3539.

29. Radford, D.R.; Challacombe, S.J.; Walter, J.D. (1999). Denture plaque and adherence of Candida albicans to denture-base materials in vivo and in vitro. Crit. Rev. Oral Biol. Med., 10, 99-116.

30. Ramage, G.; Vandewalle, K.; Wickes, B.L.; Lopez- Ribot, J.L. (2001) Characteristics of biofilm formation by Candida albicans. Rev. Iberoam. Micol., 18, 163-170.

31. Samaranayake, L.P.; MacFarlane, T.W. (1980). An in-vitro study of the adherence of Candida albicans to acrylic surfaces. Arch. Oral Biol., 25, 603-606.

32. Sen, B.H.; Kamran, E.S.; Larz, S.W. (1997). Growth patterns of Candida albicans in relation to radicular dentin. Oral Surg. Oral Med. Oral Pathol., 84, 68-73.

33. Soll, D.R. (2002). Candida commensalisms and virulence: the evolution of phenotypic plasticity. Acta Trop., 81, 101-110.

34. Tamura, N.K.; Gasparetto, A.; Svidzinski, T.I.E. (2003). Evaluation of the adherence of Candida species to urinary catheters. Mycopathologia, 156(4), 269-272.

35. Thein, Z.M.; Samaranayake, Y.H.; Samaranayake, L.P. (2006). Effect of oral bacteria on growth and survival of Candida albicans biofilms. Arch. Oral. Biol., 51, 672-680.

36. Yoshiyasu, R.Y.A. (2001). Um estudo in vitro sobre os efeitos da irradiação pelo laser de Er: YAG combinado com a terapia com flúor na resistência ácida do esmalte de dentes submetidos a aparelho ortodôntico fixo. São Paulo, Brasil, 69p. (M. Sc. Dissertation. IPEN Universidade de São Paulo). 